\title{
CLINICAL STUDY OF CARDIAC AUTONOMIC DYSFUNCTION IN HIV PATIENTS
}

\author{
H. Mallikarjun Swamy11, S. R. Chandrashekar Patil2, Sunil Gayad ${ }^{3}$
}

\section{HOW TO CITE THIS ARTICLE:}

H. Mallikarjun Swamy, S. R. Chandrashekar Patil, Sunil Gayad. “Clinical Study of Cardiac Autonomic Dysfunction in HIV Patients". Journal of Evolution of Medical and Dental Sciences 2014; Vol. 3, Issue 46, September 22;

Page: 11146-11159, DOI: 10.14260/jemds/2014/3454

ABSTRACT: BACKGROUND AND OBJECTIVES: Cardiovascular autonomic nervous dysfunction has been demonstrated to severely debilitate HIV infected patients, namely by postural hypotension and syncopes It has important implication in health care of HIV patients. METHODS: 50 patients (25 HIV +ve without AIDS and 25 HIV+ with AIDS) who fulfilled the inclusion and exclusion criteria and 50 healthy matched controls were enrolled in the study. Autonomic function was assessed by batteries of autonomic function tests. RESULTS: In the present study $16 \%$ of HIV +ve with the AIDS had abnormal autonomic dysfunction and 4\% of HIV positive without AIDS had abnormal autonomic dysfunction. Abnormalities in autonomic function occurred at all levels of CD4 counts. More number of abnormal results was found below 200 CD4 range. But the difference was not statistically significant. CONCLUSION: Cardiac autonomic nervous dysfunction is a common and relevant clinical problem it is significantly affected in both HIV positive without AIDS and HIV positive with AIDS groups. It may provide an alternative explanation for symptoms commonly observed in HIV infected individuals such as bowel and bladder dysfunction, impotence, syncope and sweating abnormalities.

KEYWORDS: HIV, AIDS, Autonomic Dysfunction, valsalva manoeuvre, heart rate.

INTRODUCTION: AIDS, (Acquired Immuno Deficiency Syndrome) is a fatal illness caused by a retrovirus known as Human Immunodeficiency virus (HIV) which breaks down the immune system, leaving the victim vulnerable to a host of opportunistic infections many of which are life threatening, neurological disorders, and unusual malignancies. ${ }^{1}$

HIV involves almost all major organ system including CNS. In addition to CNS and PNS, ANS also be involved. Autonomic nervous dysfunction has important implications in health care of HIV patients. It impairs the quality of life and can have fatal consequences. ${ }^{2,3}$ Because HIV affects various organ systems invasive procedures are often needed for diagnostic and therapeutic purposes. In late stages of HIV infection screening for autonomic dysfunction may be advisable before invasive procedures such as peri cardiocentesis because of risk of cardiovascular collapse or sudden death.

Syncopal reactions have been reported in HIV patients with abnormal autonomic function during invasive procedure. It may identify HIV infected patients with particular risk beyond their immunological deterioration and there by contribute to risk stratification.4,5There is scanty literature on autonomic effects of HIV infection in Indian patients hence this study is being taken up to address question of cardiac autonomic dysfunction in the Indian scenario.

MATERIALS AND METHODS: SOURCE OF DATA: Patients admitted to Medical wards KIMS Hospital, Hubli, with HIV infection diagnosed as per NACO guidelines will be taken for study considering the inclusion and exclusion criteria. 


\section{INCLUSION CRITERIA:}

- HIV infection diagnosed as per NACO guidelines.

\section{EXCLUSION CRITERIA:}

- H/o cardiovascular disease before testing.

- Very ill patients who are unable to perform the autonomic test manoeuvres.

- Patients with diabetes mellitus.

- Patients on Antiretroviral Therapy.

- Known alcoholics

\section{CARDIAC AUTONOMIC DYSFUNCTION WAS TESTED BY VARIOUS MANOEURES AS FOLLOWS:}

HEART RATE VARIATION TO VALSALVA MANOEUVRE: The test was performed by asking the patient to sit quietly and then to blow through mercury manometer up to $40 \mathrm{~mm} \mathrm{Hg}$. and to maintain mercury column at that level by controlled blowing into mouthpiece connected to the manometer for 15 seconds, continuous ECG was recorded during the procedure and fifteen seconds after the release of pressure. This test was performed 3 times at 1 min interval. The ratio of longest R-R interval after the maneuver to shortest interval during maneuver was measured and the result was expressed as Valsalva ratio. A Valsalva ratio of 1.21 or greater was considered normal between 1.11 to 1.20 was borderline and 1.10 or less was taken as abnormal.

HEART RATE RESPONSE TO DEEP BREATHING: The subject sits quietly and breaths deeply and evenly at six breaths per minute, five seconds inspiration and five seconds expiration. ECG was continuously recorded during the procedure. The longest and shortest R-R intervals during expiration and inspiration were measured and corresponding heart rates calculated. The difference between maximum and minimum heart rates was calculated. A difference of more than 15 beats per minute was taken as normal. A difference of 11- 15 beats per minute was considered border line and difference of less than 10 beats per minute was considered as abnormal.

HEART RATE RESPONSE TO STANDING FROM SUPINE POSITION: The ratio of the longest R-R interval to the shortest R-R interval after the patient moved quickly from supine to upright posture was noted. The ratio of 1.04 or greater was considered normal between 1.01 to 1.03 was borderline and 1 or less taken as abnormal.

BLOOD PRESSURE RESPONSE TO STANDING UP: This test was performed by measuring the blood pressure while subject was in supine posture and later by making the patient to stand up and the blood pressure was recorded after 3 minutes. A difference in systolic blood pressure after patient stands up is less than $10 \mathrm{~mm}$. of $\mathrm{Hg}$. is considered normal and fall of 11 to $29 \mathrm{~m}$. of $\mathrm{Hg}$. taken as borderline and a fall of more than $30 \mathrm{~mm}$. of $\mathrm{Hg}$. taken as abnormal.

BLOOD PRESSURE RESPONSE TO SUSTAINED HANDGRIP: Here two sphygmomanometers were used. The cuff was inflated to $10 \mathrm{~mm}$. of $\mathrm{Hg}$. basal level kept at $10 \mathrm{~mm}$ of $\mathrm{Hg}$. Then patient was asked to compress the cuff to the maximum extent with the hand. The patient was asked to maintain pressure on the cuff at $30 \%$ of maximum effort for 3 minutes. 
The blood pressure was recorded at the beginning and at the end of the procedure. Normal rise of diastolic pressure at the end of procedure is more than $16 \mathrm{~mm}$ of $\mathrm{Hg}$. A value between 11 to 15 $\mathrm{mm}$ is considered as borderline and a reading of less than $10 \mathrm{~mm}$ of $\mathrm{Hg}$ was taken as abnormal.

\begin{tabular}{|l|l|l|l|l|}
\hline S1. & Tests & Normal & Borderline & Abnormal \\
\hline 1. & Valsalva ratio & $>1.21$ & $1.11-1.20$ & 4.10 \\
\hline 2. & HR to deep breathing & $>15$ & $11-14$ & $<10$ \\
\hline 3. & HR to standing 30/15 & $>1.04$ & $1.01-1.03$ & 4.00 \\
\hline 4. & Blood pressure response & $<10(\mathrm{~mm} \mathrm{Hg})$ & $11-29(\mathrm{~mm}-\mathrm{Hg})$ & $>30(\mathrm{~mm} \mathrm{Hg})$ \\
& to standing (Orthostatic & & & \\
\hline 5. & Blood pressure response & $>16(\mathrm{~mm} \mathrm{Hg})$ & $11-15(\mathrm{~mm} \mathrm{Hg})$ & $<10(\mathrm{~mm} \mathrm{Hg})$ \\
& to sustained hand grip & & & \\
\hline
\end{tabular}

For grading of cardiovascular autonomic function, results were classified as normal, borderline, and abnormal (scored 0, 1 and 2 respectively). An overall score $\leq 3$ considered to indicate normal autonomic function. Scores $>3$ and $<8$ were considered borderline and scores $\geq 8$ were judged abnormal.

\section{OBSERVATION:}

COMMON MODE OF PRESENTATION AND SYMPTOMS OF THE PATIENTS.

DISTRIBUTION OF SUBJECTS BY CD4 COUNT.

\begin{tabular}{|c|c|c|}
\hline CD4 count cells $/ \mu l$ & AIDS Patients & HIV+ve Patients \\
\hline $0-50$ & 4 & - \\
\hline 51-100 & 5 & - \\
\hline $101-200$ & 10 & - \\
\hline 201-300 & 3 & 3 \\
\hline $301-400$ & 2 & 10 \\
\hline $401-500$ & 1 & 4 \\
\hline$>500$ & $\mathbf{0}$ & 8 \\
\hline Tetal & 25 & 25 \\
\hline
\end{tabular}




\section{ORIGINAL ARTICLE}

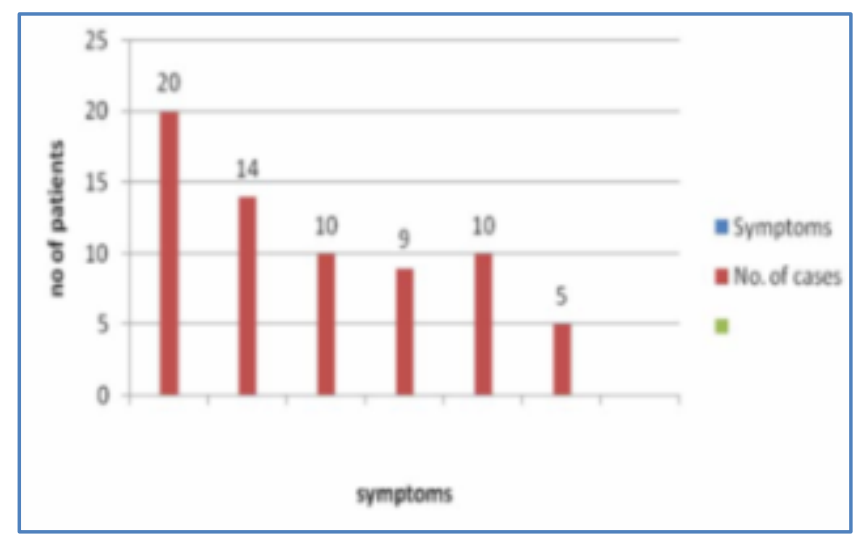

The most common symptoms were dizziness and lower GI symptoms and least common were sexual disturbances.

DISTRIBUTION OF SUBJECTS BY CD4 COUNT

\begin{tabular}{|c|c|c|}
\hline CD4 count cells $\mu \mathrm{l}$ & AIDS Patients & HIV+ve Patients \\
\hline $0-50$ & 4 & . \\
\hline $51-100$ & 5 & - \\
\hline $101-200$ & 10 & - \\
\hline $201-300$ & 3 & 3 \\
\hline $301-400$ & 2 & 10 \\
\hline $401-500$ & 1 & 4 \\
\hline$>500$ & 0 & 8 \\
\hline Total & 25 & 25 \\
\hline
\end{tabular}

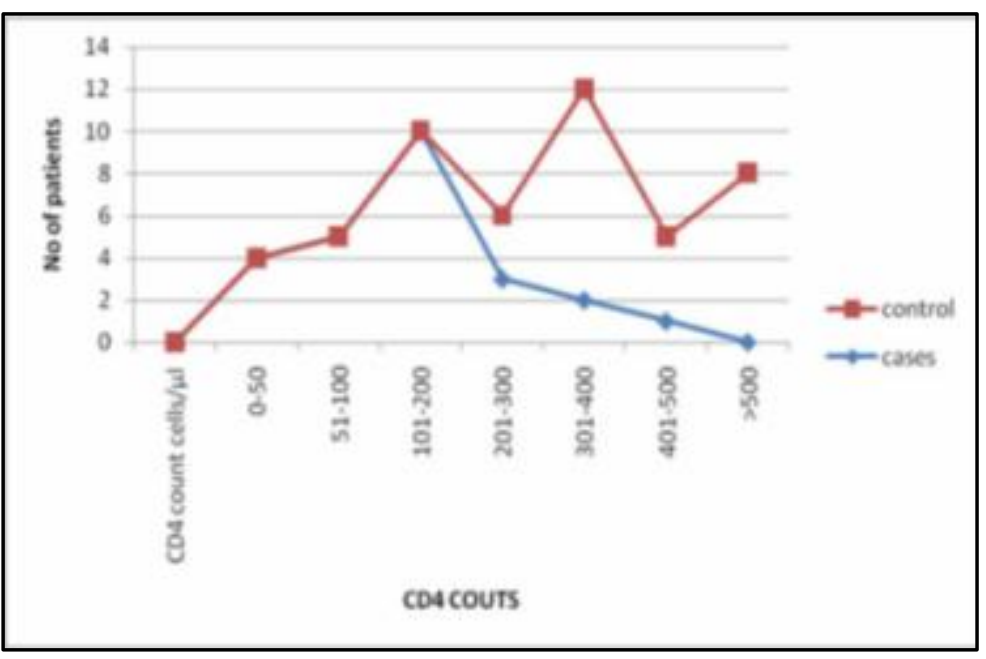


The present study showed majority of the AIDS patients had a CD4 range of 101-200 and majority of the HIV positive patients had a CD4 count in the range of 301-400.

SHOWING THE ANALYSIS OF HEART RATE RESPONSE TO STANDING BETWEEN HIV POSITIVE GROUP, AIDS GROUP AND CONTROL GROUP

\begin{tabular}{|c|c|c|c|c|}
\hline $\begin{array}{c}\text { Heart rate respouse } \\
\text { to standing }\end{array}$ & $\begin{array}{c}\text { HIV positive } \\
\text { without AIDS }\end{array}$ & $\begin{array}{c}\text { HIV positive } \\
\text { with AIDS }\end{array}$ & Control & Total \\
\hline \multirow{2}{*}{ Normal } & 11 & 11 & 48 & 70 \\
\cline { 2 - 5 } & $44.0 \%$ & $44.0 \%$ & $96.0 \%$ & $70.0 \%$ \\
\hline \multirow{2}{*}{ Border Line } & 10 & 6 & 2 & 18 \\
\cline { 2 - 5 } & $40.0 \%$ & $24.0 \%$ & $4.0 \%$ & $18.0 \%$ \\
\hline \multirow{2}{*}{ Abnormal } & 4 & 8 & & 12 \\
\cline { 2 - 5 } & $16.0 \%$ & $32.0 \%$ & 0 & $12.0 \%$ \\
\hline \multirow{2}{*}{ Total } & 25 & 25 & 50 & 100 \\
\cline { 2 - 5 } & $100.0 \%$ & $100.0 \%$ & $100.0 \%$ & $100.0 \%$ \\
\hline
\end{tabular}

Chi-:quare-32.19, p value 0.001 , Highly significant, $d f-1$

Showing the analysis of heart rate response to standing between HIV positive group, AIDS group and control group

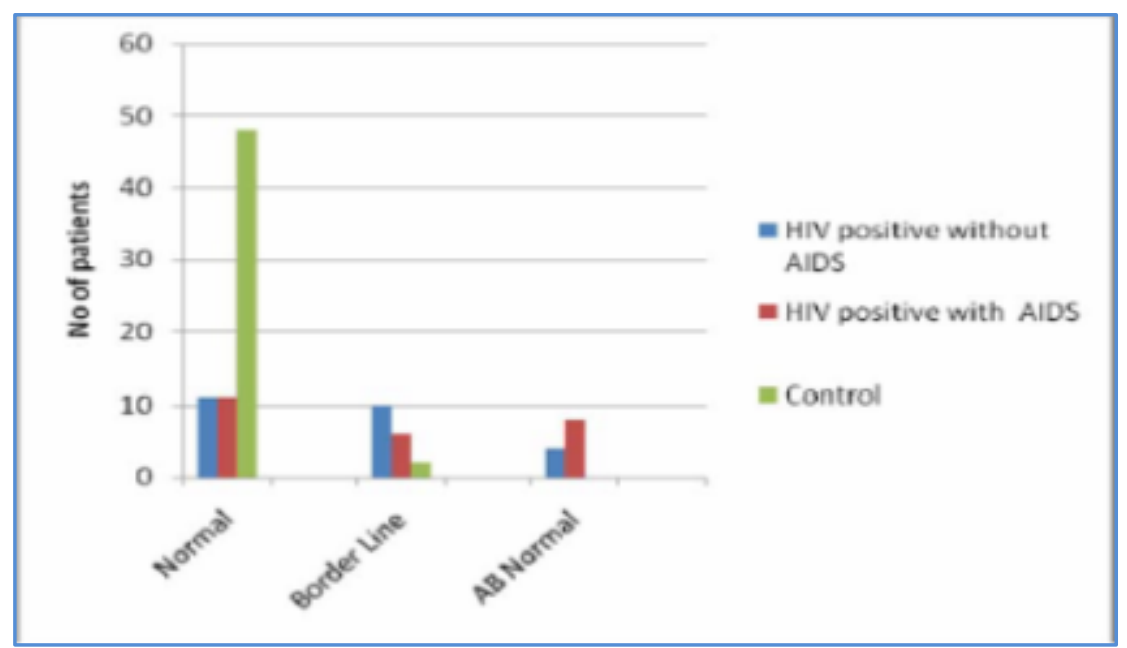

When the result of heart rate variation to standing was analyzed. It was found that there was significant differences between HIV/AIDS patients group and control group $(\mathrm{P}=0.000)$. 
Showing Analysis of valsalva ratio in HIV positive/aids group and Contro Group

\begin{tabular}{|c|c|c|c|c|}
\hline $\begin{array}{c}\text { Valsalva } \\
\text { Ratio }\end{array}$ & $\begin{array}{c}\text { HIV positive without } \\
\text { AIDS }\end{array}$ & $\begin{array}{c}\text { HIV positive +re } \\
\text { with AIDS }\end{array}$ & Control & Total \\
\hline \multirow{2}{*}{ Normal } & 5 & 4 & 46 & 55 \\
\cline { 2 - 5 } & $20.0 \%$ & $16.0 \%$ & $92.0 \%$ & $55.0 \%$ \\
\hline \multirow{2}{*}{ Border Line } & 8 & 5 & 4 & 17 \\
\cline { 2 - 5 } & $32.0 \%$ & $20.0 \%$ & $8.0 \%$ & $17 \%$ \\
\cline { 2 - 5 } & 12 & 16 & & 28 \\
\hline \multirow{2}{*}{ AB Notal } & $48.0 \%$ & $64.0 \%$ & 50 & 100 \\
\cline { 2 - 5 } & $100.0 \%$ & $100.0 \%$ & $100.0 \%$ & $100.0 \%$ \\
\hline
\end{tabular}

Chi-square- 55.31 , p value -60.001 , Highly significant, df -1

Analysis of valsalva ratio in HIV positive/AIDS group and control group

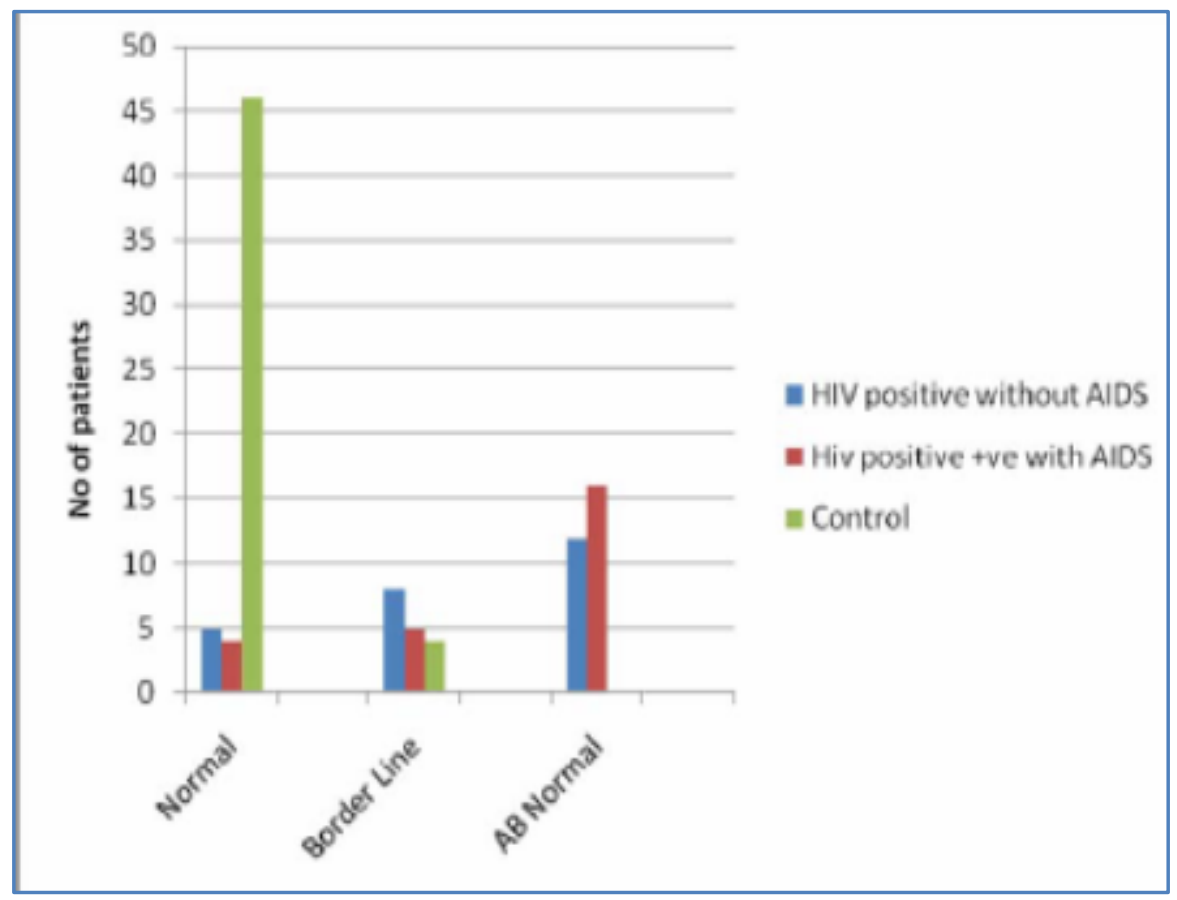

When the results of valsalva ratio was analyzed it was found that there was significant difference between HIV/AIDS group and control group ( $p$ value $<0.001$ ). 
Showing analysis of heart rate response to deep breathing between HIV positive/aids and control group.

\begin{tabular}{|c|c|c|c|c|}
\hline $\begin{array}{l}\text { Heart rate response to } \\
\text { deep breathing }\end{array}$ & $\begin{array}{l}\text { HIV positive } \\
\text { without AIDS }\end{array}$ & $\begin{array}{c}\text { HIV positive } \\
+ \text { with } \\
\text { AIDS }\end{array}$ & Control & Total \\
\hline \multirow[b]{2}{*}{ Normal } & 9 & 5 & 46 & 60 \\
\hline & $36.0 \%$ & $20.0 \%$ & $92.0 \%$ & $60.0 \%$ \\
\hline \multirow[b]{2}{*}{ Border Line } & 6 & 6 & 2 & 14 \\
\hline & $24.0 \%$ & $24.0 \%$ & $4.0 \%$ & $14.0 \%$ \\
\hline \multirow[b]{2}{*}{ Abnormal } & 10 & 14 & 2 & 26 \\
\hline & $40.0 \%$ & $56.0 \%$ & $4.0 \%$ & $26.0 \%$ \\
\hline \multirow[b]{2}{*}{ Total } & 25 & 25 & 50 & 100 \\
\hline & $100.0 \%$ & $100.0 \%$ & $100.0 \%$ & $100.0 \%$ \\
\hline
\end{tabular}

Chi-square-42.04.p value- $<0.001$, Highly significant,df-1

Showing the analysis of heart rate response to deep breathing between HIV positive/AIDS in control group

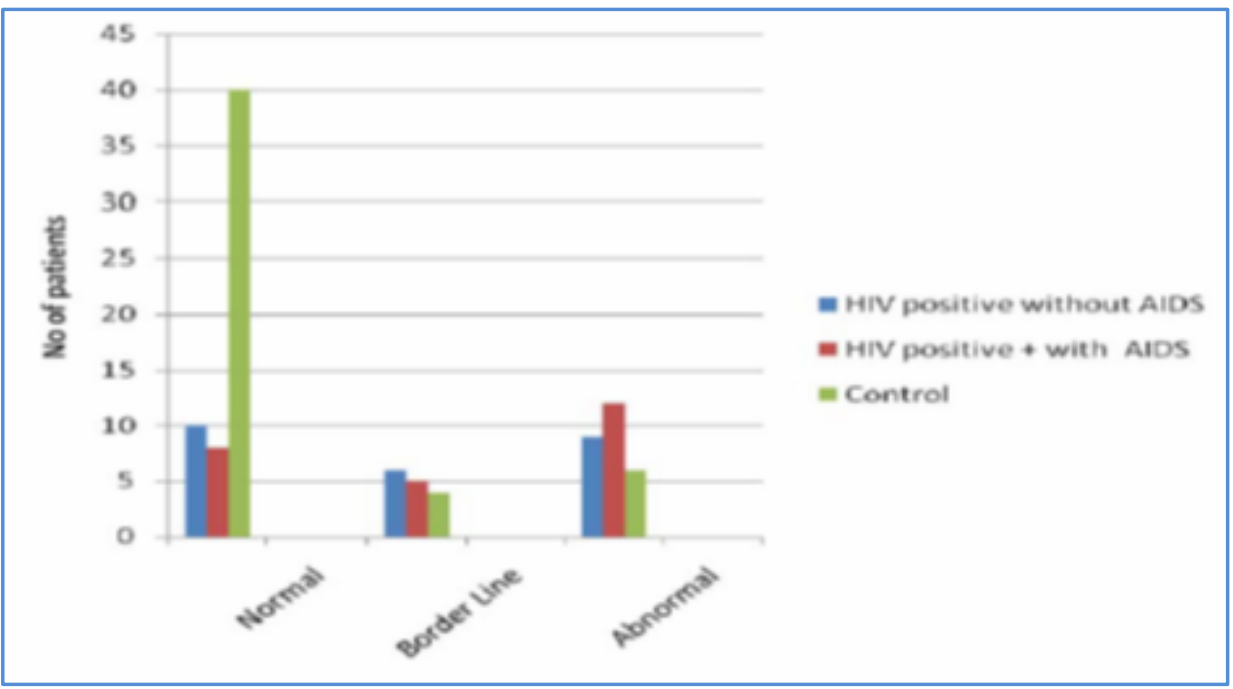

The results of heart rate response to deep breathing variation to standing were analyzed. It was found that there was significant differences between HIV/AIDS patients group and control group $(\mathrm{P}=0.000)$ Showing the analysis of systolic BP response to standing between HIV positive/AIDS and control group. 


\section{ORIGINAL ARTICLE}

\begin{tabular}{|l|c|c|c|c|}
\hline $\begin{array}{c}\text { Systolic BP respouse } \\
\text { to standing }\end{array}$ & $\begin{array}{c}\text { HIV +ve } \\
\text { without AIDS }\end{array}$ & $\begin{array}{c}\text { HIV +ve with } \\
\text { AIDS }\end{array}$ & Control & Total \\
\hline \multirow{2}{*}{ Normal } & 22 & 17 & 46 & 85 \\
\cline { 2 - 5 } & $88 \%$ & $68 \%$ & $92 \%$ & $85 \%$ \\
\hline \multirow{2}{*}{ Border Line } & 3 & 6 & 4 & 13 \\
\hline \multirow{2}{*}{ Absormal } & $12 \%$ & $24 \%$ & $8.0 \%$ & $13 \%$ \\
\hline \multirow{2}{*}{ Total } & - & 2 & - & 2 \\
\cline { 2 - 6 } & $\mathbf{2 5}$ & $\mathbf{2 5}$ & - & $2.0 \%$ \\
\hline & $100.0 \%$ & $100.0 \%$ & $100.0 \%$ & $100.0 \%$ \\
\hline
\end{tabular}

By applying Fisher’ Exact test p value $<0.05$,significant

Showing the analysis of systolic BP response to standing between HIV positive/AIDS and control group

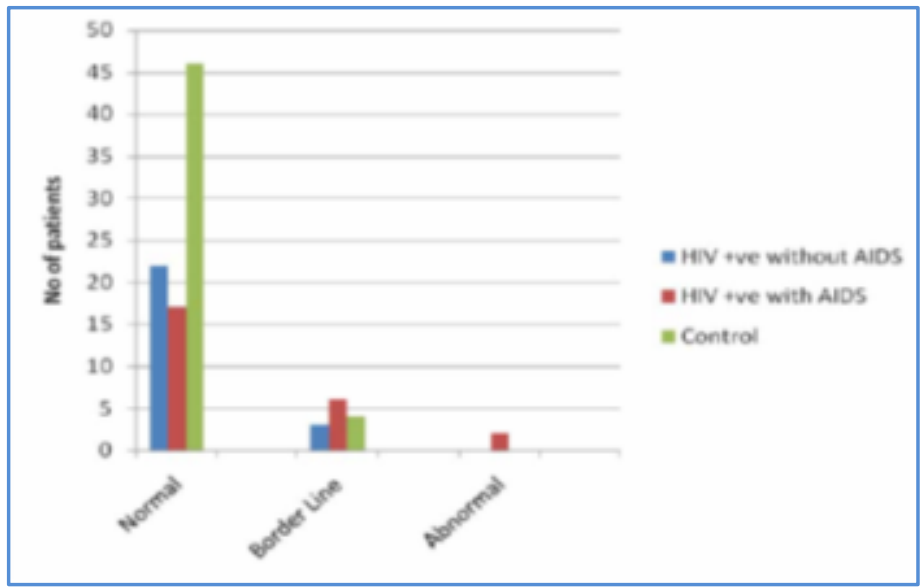

When the results of systolic BP response to standing was analyzed. It was found that there was significant differences between HIV/AIDS patients group and control group $(\mathrm{P}<0.05)$.

Showing the Analysis of Diastolic BP response to Sustained Hand Grip between HIV/AIDS and Control.

\begin{tabular}{|c|c|c|c|c|}
\hline $\begin{array}{l}\text { Diastolic BP response to } \\
\text { sustained hand grip }\end{array}$ & $\begin{array}{l}\text { HIV +ve without } \\
\text { AIDS }\end{array}$ & $\begin{array}{l}\text { HIV +ve } \\
\text { with AIDS }\end{array}$ & Control & Total \\
\hline \multirow[b]{2}{*}{ Normal } & 21 & 19 & 44 & 55 \\
\hline & $84 \%$ & $76 \%$ & $88 \%$ & $55.0 \%$ \\
\hline \multirow[b]{2}{*}{ Berder Line } & 3 & 4 & 6 & 31 \\
\hline & $12 \%$ & $16 \%$ & $12 \%$ & $31.0 \%$ \\
\hline \multirow[b]{2}{*}{ Abnormal } & 1 & 2 & 0 & 14 \\
\hline & $4 \%$ & $8 \%$ & $0 \%$ & $14.0 \%$ \\
\hline \multirow[b]{2}{*}{ Total } & 25 & 25 & so & 100 \\
\hline & $100.0 \%$ & $100.0 \%$ & $100.0 \%$ & $100.0 \%$ \\
\hline
\end{tabular}

Chi-square-1.19, p 0.05, not significant,df-1 


\section{ORIGINAL ARTICLE}

Showing the analysis of diastolic BP response to sustained hand grip between HIV/AIDS and control group

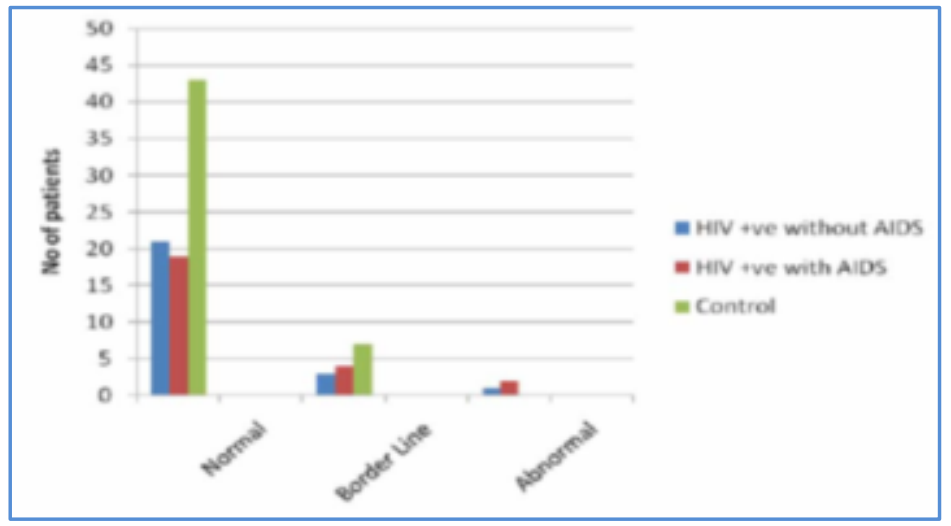

When the results of diastolic BP response to sustained handgrip was analyzed. It was found that there was no stastical differences between HIV/AIDS patients group and control group ( $\mathrm{P}>0.05)$.

SHOWING FREQUENCY DISTRIBUTION OF NORMAL BORDERLINE, ABNORMAL AUTONOMIC FUNCTION BETWEEN HIV POSITIVE, AIDS AND CONTROL GROUP

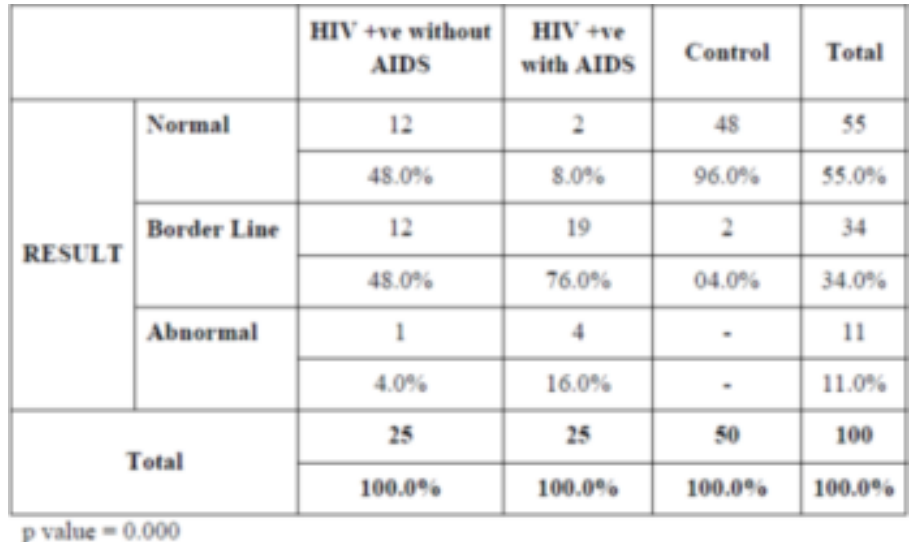

Showing frequency distribution of normal borderline, abnormal autonomic function between HIV positive, AIDS and control group

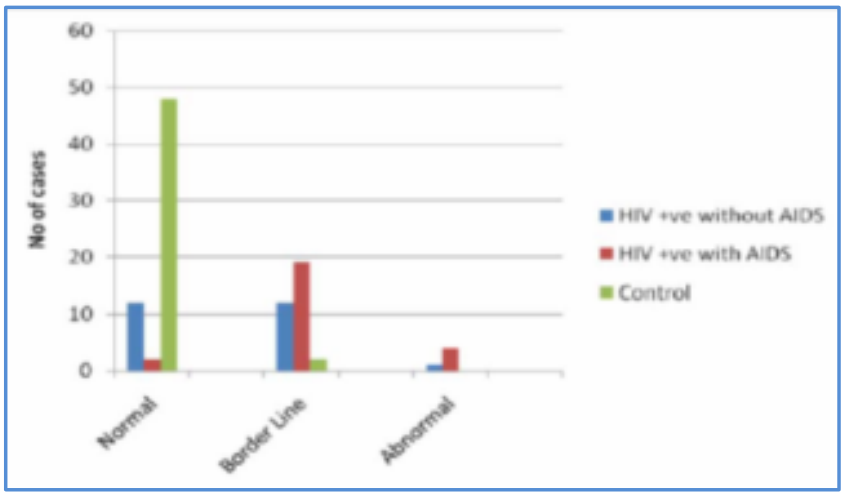


When the results of autonomic function tests was analyzed in HIV positive, AIDS and control group. It was found that autonomic function tests was abnormal in 4(16\%), AIDS patients, but in only $1(4 \%)$ HIV positive patients without AIDS. None of the HIV negative patients had abnormal function. Only 2 (8\%), of 25 AIDS patients had completely normal autonomic function. More than $45 \%$ of HIV infected patients and 76\% of AIDS had borderline results. The results were statistically significant (p value.000).

COMPARATIVE STUDY OF ABNORMAL AUTONOMIC FUNCTION BETWEEN AIDS GROUP AND HIV POSITIVE GROUP

a) VALSALVA RATIO:

\begin{tabular}{|l|c|c|}
\hline VALSALVA RATIO: & $\begin{array}{c}\text { HIV +ve with } \\
\text { AIDS }\end{array}$ & $\begin{array}{c}\text { HIV +ve } \\
\text { without } \\
\text { AIDS }\end{array}$ \\
\hline \multirow{2}{*}{ Normal } & 4 & 5 \\
\hline \multirow{2}{*}{ Border Line } & $16 \%$ & $20 \%$ \\
\hline \multirow{2}{*}{ Abnormal } & 5 & 8 \\
\hline \multirow{2}{*}{ Total } & $\mathbf{2 0 \%}$ & $32 \%$ \\
\cline { 2 - 3 } & $\mathbf{1 6}$ & 12 \\
\cline { 2 - 3 } & $\mathbf{6 4} \%$ & $48 \%$ \\
\hline
\end{tabular}

Fisher's Exact Test-p value $>0.05$, Not significant, df-1.

\section{b) HEART RATE RESPONSE TO DEEP BREATHING}

\begin{tabular}{|c|c|c|}
\hline $\begin{array}{l}\text { Heart rate response to } \\
\text { deep breathing }\end{array}$ & $\begin{array}{c}\text { HIV +ve with } \\
\text { AIDS }\end{array}$ & $\begin{array}{c}\text { HIV +ve } \\
\text { without } \\
\text { AIDS }\end{array}$ \\
\hline \multirow{2}{*}{ Normal } & 5 & 9 \\
\hline \multirow{2}{*}{ Border Line } & $20 \%$ & $36 \%$ \\
\hline \multirow{2}{*}{ Abnormal } & 6 & 6 \\
\hline \multirow{2}{*}{ Total } & $\mathbf{2 4 \%}$ & $\mathbf{2 4 \%}$ \\
\cline { 2 - 3 } & 14 & 10 \\
\hline & $\mathbf{2 5}$ & $40 \%$ \\
\hline
\end{tabular}

Chi-square test-1.59, $\mathrm{p}$ value $>0.05$, Not significant, $\mathrm{df}-1$. 


\section{ORIGINAL ARTICLE}

\section{c) HEART RATE RESPONSE TO STANDING}

\begin{tabular}{|l|c|c|}
\hline $\begin{array}{l}\text { Heart rate response to } \\
\text { standing }\end{array}$ & $\begin{array}{c}\text { HIV +ve with } \\
\text { AIDS }\end{array}$ & $\begin{array}{c}\text { HIV +ve } \\
\text { without } \\
\text { AIDS }\end{array}$ \\
\hline \multirow{2}{*}{ Normal } & 17 & 22 \\
\hline \multirow{2}{*}{ Border Line } & $68 \%$ & $88 \%$ \\
\hline \multirow{2}{*}{ Abnermal } & 6 & 3 \\
\hline \multirow{2}{*}{ Total } & $24 \%$ & $12 \%$ \\
\hline & 25 & 0 \\
\cline { 2 - 4 } & $100.0 \%$ & $100.0 \%$ \\
\hline
\end{tabular}

d) SYSTOLIC FALL IN BP ON STANDING

\begin{tabular}{|c|c|c|}
\hline $\begin{array}{l}\text { Systolic fall in BP on } \\
\text { standing }\end{array}$ & $\begin{array}{c}\text { HIV +ve with } \\
\text { AIDS }\end{array}$ & $\begin{array}{c}\text { HIV +ve } \\
\text { without } \\
\text { AIDS }\end{array}$ \\
\hline \multirow[b]{2}{*}{ Normal } & 17 & 22 \\
\hline & $68 \%$ & $88 \%$ \\
\hline \multirow[b]{2}{*}{ Border Line } & 6 & 3 \\
\hline & $24 \%$ & $12 \%$ \\
\hline \multirow[b]{2}{*}{ Abnormal } & 2 & 0 \\
\hline & $8 \%$ & $0 \%$ \\
\hline \multirow[b]{2}{*}{ Total } & 25 & 25 \\
\hline & $100.0 \%$ & $100.0 \%$ \\
\hline
\end{tabular}

Chi-square test-2.91:p value $>0.05$, Not significant,df-1.

\section{e) DIASTOLIC RISE IN BP ON SUSTAINED HAND GRIP}

\begin{tabular}{|l|c|c|}
\hline $\begin{array}{l}\text { Diastolic rise in BP on } \\
\text { sustained hand grip }\end{array}$ & $\begin{array}{c}\text { HIV +ve with } \\
\text { AIDS }\end{array}$ & $\begin{array}{c}\text { HIV +ve } \\
\text { without } \\
\text { AIDS }\end{array}$ \\
\hline \multirow{2}{*}{ Normal } & 19 & 21 \\
\hline \multirow{2}{*}{ Border Line } & $\mathbf{7 6 \%}$ & $84 \%$ \\
\hline \multirow{2}{*}{ Abnormal } & $16 \%$ & 3 \\
\cline { 2 - 4 } & 2 & $12 \%$ \\
\hline \multirow{2}{*}{ Total } & $8 \%$ & $4 \%$ \\
\hline
\end{tabular}

Chi-square test $-0.5, \mathrm{p}$ value $>0.05 ;$ Not significant;df -1 . 
When the results of abnormal autonomic function tests were analyzed there is no significant difference between AIDS group and HIV group. However the most pronounced abnormalities were found in patients with AIDS, but across groups there was a trend towards increasing autonomic dysfunction, from asymptomatic HIV disease to AIDS. This shows that dysfunction can occur at any stage of the disease.

\section{SHOWING THE CORRELATION OF CD4 CELL COUNT WITH AUTONOMIC DYSFUNCTION.}

\begin{tabular}{|c|c|c|c|c|c|c|}
\hline & \multicolumn{4}{|c|}{ CD4 cell count } & \multirow{3}{*}{$\begin{array}{r}\text { Total } \\
14\end{array}$} \\
\hline & & \multirow{2}{*}{$\begin{array}{r}<00 \\
2\end{array}$} & \multirow{2}{*}{$\begin{array}{c}201- \\
400 \\
3\end{array}$} & \multirow{2}{*}{$\frac{401-600}{6}$} & \multirow{2}{*}{$\begin{array}{c}600+ \\
3\end{array}$} & \\
\hline \multirow{6}{*}{ RESULT } & \multirow[t]{2}{*}{ Normal } & & & & & \\
\hline & & $10 \%$ & $16.6 \%$ & $100 \%$ & $50 \%$ & $28 \%$ \\
\hline & \multirow[t]{2}{*}{ Border Line } & 15 & 14 & - & 2 & 31 \\
\hline & & $75 \%$ & $77.7 \%$ & $\cdot$ & $33.3 \%$ & $62 \%$ \\
\hline & \multirow[t]{2}{*}{ AB Normal } & 3 & 1 & $\cdot$ & 1 & 5 \\
\hline & & $15 \%$ & $5.6 \%$ & - & $16 \%$ & $10 \%$ \\
\hline \multicolumn{2}{|c|}{ Total } & 20 & 18 & 6 & 6 & 50 \\
\hline
\end{tabular}

In the present study patients autonomic dysfunction occurred at wide range of CD4 cell count. However more number of abnormal results were found below 200 CD4 range and more number of normal results were found in CD4 Count range of 401-600.

DISCUSSION: It was observed in this study that there was evidence of substantial autonomic dysfunction in HIV and AIDS patients compared with controls. Incidence of cardiac autonomic nervous dysfunction increases with HIV disease progression.

HIV AND WITH AUTONOMIC NEUROPATHY: Autonomic dysfunction occurs more frequently and with greater severity in patients with AIDS however it may be present in the early stages of HIV infection and appears to progress during the illness. ${ }^{6}$ Early clinical features of autonomic dysfunction in HIV infected patients include syncope, pre syncope, diminished sweating, diarrhea, bladder dysfunction, impotence. Subclinical autonomic neuropathy has been found in up to $50 \%$ of HIV infected patients.

\section{PATHOGENESIS OF THE AUTONOMIC NERVOUS SYSTEM:}

DYSFUNCTION OF HIV INFECTIONS: HIV-1 enters the brain early in the course of the disease probably at the time of sero conversion. Entry is by way of blood borne infection and to a lesser extent by "spread" from chronic meningeal infection which in turn is likely related to low level infection of the choroid plexus. ${ }^{7}$ Such low level infection is kept in check by a relatively intact immune system but as HIV-1 disease progresses, brain infection becomes unchecked and compensatory 
mechanisms are activated that result in the production of various cytokines that over a period of time lead to central nervous system dysfunction. Additionally, the low level brain infection is now capable of being amplified by the similarly unchecked systemic disease thereby accounting for the perivascular distribution.

The tissue damaged by the cytokines then becomes secondarily infected both by the now unchecked local brain infection and by the systemically circulating infected cells. Moreover, as HIV-1 disease advances there is a reduction in CD4 + cells and there is a selection towards macrophage tropic isolates of HIV-1 that further infect the brain: essentially the brain cells that are of macrophage lineage namely the microglial cells.8,9

At the cellular level, the envelope glycoprotein of HIV-1 gpl20 is toxic to rodent neurons and the neuronal killing is critically dependent upon the presence of cells of the macrophage lineage ${ }^{10,11 .}$ Furthermore, the precise mechanism of neuronal damage is by way of activation of the N-methyl Daspartate receptor with consequent influx into the cell of calcium and secondary synthesis of nitric oxide in those neurons containing nitric oxide synthetase.

Not only do macrophage lineage cells serve to facilitate neuronal damage but it appears that they release neuronotoxic factors as well. Some of these are as yet undefined, while others are arachidonic acid metabolites and platelet activating factor, that require cell-to-cell interactions for toxicity.12,13

Peripheral nerves are also affected by the cytokines that are released by macrophage lineage cells in an attempt to control infection. Another possible mechanism is the documented methylation defect in HIV-1 infected individuals that may lead to changes similar to cyanocobalamin deficiency. The third possibility, namely direct infection of oligodendrocytes. ${ }^{14}$

CONCLUSION: Cardiac autonomic nervous dysfunction is a common and relevant clinical problem it is significantly affected in both HIV positive without AIDS and HIV positive with AIDS groups. It may provide an alternative explanation for symptoms commonly observed in HIV infected individuals such as bowel and bladder dysfunction, impotence, syncope and sweating abnormalities.

Reduced heart rate variability is the commonest manifestation of autonomic dysfunction noted in both HIV positive without AIDS and HIV positive with AIDS groups. Diastolic BP responses to sustained handgrip have a limited role in discriminating autonomic function in HIV infected patients. There is no statistically significant correlation with the CD4 level and the presence of autonomic nervous system dysfunction in both the groups.

\section{BIBLIOGRAPHY:}

1. Park K; AIDS; Park's textbook of Preventive and social medicine. Feb 2007; 19th h edition: page 285-297.

2. Fauci AS, Lane HC: Human Immunodeficiency virus disease: AIDS and Related Disorders; Harrisons Principles of Internal Medicine; Volume N 1; 17th edition; Chapter; 182; Page: 11371204.

3. Becker K, Gorlach I, Frieling T, Hausinger D. Characterisation and natural course of cardiac dysfunction in HIV, AIDS 1997; 11: 751-7.

4. Rogstad K, Shah R, Tesfaladet G, Abdullah M, Ahmed-Jusuf I. Cardiovascular autonomic dysfunction in HIV infected patients. Sex Transm Inf 1999; 95: 264-7. 
5. Miltal CM, Wig N, Mishra S, Deepak KK. Heart rate variability in human immunodeficiency virus positive individuals. International Journal of Cardiology 2004; 94 (1): 1-6.

6. Nzubontane D, Ngu BK. Cardiovascular autonomic dysfunction in Africans infected with HIV J R Soc Med 2002; 95: 445-44.

7. World Health Organization. Scaling up antiretroviral therapy in resource limited Settings. Treatment guidelines for a Public health approach 2003. Revision. World Health Organization, Geneva 2004. Available at www.who.int. Accessed on 20th June 2004.

8. Tripathi AK. Diagnosis of HIV infection and AIDS. Indian guidelines. Chapter 3.2 In: Das S editor. Medicine Update. Volume 13, 2003. Association of Physicians of India 2003: 86-90.

9. Lafeuillade A, Tamalet C, Pellegrino P, Micco P, Vignoli C, Quilichini R. Correlation between Surrogate markers, viral load and disease Progression in HIV-1 infection J Acquir Immune Defic Syndr 1994; 7: 1028-1033.9. Katz MH, Hollander H. HIV infection, Chapter 31. In: Tierney ML, Mc Phee.

10. Papadakis MA, editors. Current Medical diagnosis and treatment 2004. 43 ${ }^{\text {rd }}$ edition, McGraw Hill Publication 2004: 1263- 1292.

11. Tsoukas CM, Bernard NF. Markers predicting progression of human Immunodeficiency virus related disease. Clinical Microbiology Reviews 1994, 7: 14-28.

12. Sabin CA, Lepri AC, Devereux H, Phillips AN, Loveday C, Lee CA. Relationship among the detection of p24 antigen. Human Immunodeficiency virus (HIV) RNA level. CD4 cell count and disease progression in HIV infected individuals with hemophilia J infect Dis 2001; 184: 511514.

13. Hughes MD, Stein DS, Gundacker HM, Valentine FT, Phair JP, Volberding PA. Within subject variation in CD4 lymphocytes count in asymptomatic Human Immunodeficiency virus infection: Implications for patient monitoring. J Infect Dis 1994; 162: 28-36.

14. Kelly M. Natural history of HIV infection. Chapter 3 In: Hoy J, Lewin S editors. HIV management in Australasia a guide for clinical care. Australian Society for HIV Medicine Inc. 2003: 41-49.

\section{AUTHORS:}

1. H. Mallikarjun Swamy

2. S. R. Chandrashekar Patil

3. Sunil Gayad

\section{PARTICULARS OF CONTRIBUTORS:}

1. Professor \& HOD, Department of Medicine, Karnataka Institute of Medical Sciences, Hubli, Karnataka.

2. Junior Resident, Department of Medicine, Karnataka Institute of Medical Sciences, Hubli, Karnataka.

3. Assistant Professor, Department of Medicine, Karnataka Institute of Medical Sciences, Hubli, Karnataka.

\section{NAME ADDRESS EMAIL ID OF THE CORRESPONDING AUTHOR: \\ Dr. S. R. Chandrashekar Patil, Srinagar, $6^{\text {th }}$ Cross, \\ Talur Road, Bellary. \\ Email: cspatil360@gmail.com}

Date of Submission: 16/09/2014. Date of Peer Review: 17/09/2014. Date of Acceptance: 18/09/2014. Date of Publishing: 19/09/2014. 